\title{
SPECIAL FEATURE: PREFACE \\ Recent Monetary Policy \\ Preface to the special feature on recent monetary policy
}

\author{
Naotsugu Hayashi ${ }^{1}$
}

Received: 11 May 2019 / Accepted: 28 May 2019 / Published online: 24 June 2019

(C) Japan Economic Policy Association (JEPA) 2019

The International Journal of Economic Policy Studies, IJEPS, is now published by Springer-Nature from Vol. 13 in 2018. The first special issue on Energy Market Reform has been published in 2019. This second special issue is on recent monetary policy, based on the plenary session of the 17th International Conference of the Japan Economic Policy Association, JEPA, held in Fujisawa-city, Kanagawa, Japan, hosted by Keio University, in 2018.

The main theme of the plenary session is "Active Monetary Easing and Stable Growth Policy". A global financial crisis (GFC) occurred in 2008, triggered by the "Lehman Shock" in September 2008. After that, not only advanced countries but also developing countries experienced a prolonged deflation, comprising a serious economic downturn and sustained decline in prices. Many countries mobilized economic policies such as monetary and fiscal policies and industrial policies to try to escape from the serious deflation, and to aim for recovery of stable growth. In fiscal policy, governments issued a large amount of deficit government bonds, and implemented effective demand policies for public works projects. In addition, in monetary policy, central banks introduced non-traditional policies such as zero interest rate policy (ZIR), negative interest rate policy (NIR), and bold quantitative monetary easing $(\mathrm{QE})$, but they have not been achieving the desired effects.

Then, the JEPA determined to hold the plenary session, whose main theme was "Active Monetary Easing and Stable Growth Policy" to investigate the causes of the serious deflation, to analyze the effects of these new non-traditional policies on stable growth of the economy, and to clarify the effective policies to overcome deflation and recover stable growth.

In the plenary session on "Active Monetary Easing and Stable Growth Policy", Professor Jerry L. Jordan, of the Pacific Academy for Advanced Studies, gave a keynote lecture titled "Issues and Challenges of Monetary and Fiscal Policies Caused by Quantitative Easing by Central Banks". Professor Naotsugu Hayashi, of Hosei University, presented comments and questions on the lecture.

Professor Sayuri Shirai, of Keio University, presented a keynote lecture titled "Overview of Bank of Japan's Monetary Easing Policy". Professor Megumu

Naotsugu Hayashi

n.hayashi@ hosei.ac.jp

1 Hosei University, Tokyo, Japan 
Kinugawa, of the International University of Kagoshima, presented comments and questions on the lecture.

Professor Emeritus Shimizu, of Hitotsubashi university, gave a keynote lecture titled "Are Non-Traditional Monetary Policies Effective for Stable Growth?". Professor Keiichiro Kobayashi, of Keio University, presented comments and questions on the lecture.

All these presenters and discussants revised their papers based on the discussions and comments, and referees of the IJEPS refereed these papers. This special issue is the product of a compilation of these studies and arguments. 